\title{
in vitro and in silico Studies of Interaction of Synthetic 2,6,9-Trisubstituted Purine Kinase Inhibitors BPA-302, BP-21 and BP-117 With Liver Drug-Metabolizing Cytochromes P450
}

\author{
Alena ŠPIČÁKOVÁ ${ }^{1}$, Petr KRAUS ${ }^{1,2}$, Tomáš GUCKÝ ${ }^{2}$, Vladimír KRYŠTOF ${ }^{2}$, Miroslav \\ STRNAD $^{2}$, Václav BAZGIER ${ }^{3}$, Michal OTYEPKA ${ }^{3}$, Vendula KUBÍČKOVÁ ${ }^{1}$, Martin \\ PORUBA $^{1}$, Zuzana RÁCOVÁ ${ }^{1}$, Iveta ZAPLETALOVÁ ${ }^{1}$, Pavel ANZENBACHER ${ }^{1}$
}

${ }^{1}$ Department of Pharmacology Faculty of Medicine, Palacký University Olomouc, Olomouc, Czech Republic, ${ }^{2}$ Laboratory of Growth Regulators, Palacký University Olomouc and Institute of Experimental Botany, Czech Academy of Sciences, Olomouc, Czech Republic, ${ }^{3}$ Regional Centre of Advanced Technologies and Materials, Palacký University Olomouc, Olomouc, Czech Republic

Received October 8, 2019

Accepted October 26, 2019

\section{Summary}

An evaluation of possible interactions with enzymes of drug metabolism (cytochromes P450, CYP) is an important part of studies on safety and, in general, on the properties of any drug or biologically active compound. The article is focused on the preliminary metabolic study of selected 2,6,9-trisubstituted purine kinase inhibitors with significant anticancer activities which we have developed. The compounds BP- 21 and BP- 117 represent strong CDK inhibitors and the compound BPA-302 was developed as selective FLT3-ITD kinase inhibitor. Here, emphasis is placed on interactions of these compounds with the nine most important forms of CYP to evaluate the possibility of inhibition of these enzymes. The possibility of their inhibitory effect was studied in vitro on selected human liver microsomal CYP enzymes. The most affected enzyme was CYP2C19. Its activity dropped to $22 \%$ of its original value by BPA-302, to $13 \%$ by BP- 21 and to $6 \%$ by BP-117 at the highest concentration tested $\left(250 \mu \mathrm{mol} \cdot \mathrm{l}^{-1}\right)$. The results suggest that the metabolism of concomitantly administered drugs should not be significantly affected at lower doses. Molecular docking of BPA-302 indicated that it can bind to active site of both CYP2C19 and CYP2D6 enzymes above the heme cofactor corroborating the experimental data.

\section{Key words}

Cytochrome P450 inhibition - High performance liquid chromatography • Cyclin-dependent kinase inhibitor • FLT3-ITD inhibitor • Drug metabolism

\section{Corresponding author}

P. Anzenbacher, Department of Pharmacology, Faculty of Medicine, Palacký University Olomouc, Hněvotínská 3, 77515 Olomouc, Czech Republic. E-mail: anzen@seznam.cz

\section{Introduction}

The cyclin-dependent kinases (CDKs) are essential regulators of cell cycle and apoptosis. During the cell cycle, they are activated by cyclins and phosphorylate target molecules, such as transcriptional regulators, which in turn induce the expression of phasespecific genes, stimulate DNA replication, or initiate mitosis. CDK control functions are impaired in most types of cancer cells (Hanahan and Weinberg 2011). Therefore, pharmacological inhibition of CDKs has become a potential therapeutic method for cancer treatment (Otto and Sicinski 2017). (R)-roscovitine, also known as seliciclib or CYC202, is pan-selective ATPcompetitive inhibitor of $\mathrm{CDK} 1,2,5,7$ and 9. It was evaluated in combination with sapacitabine in patients with advanced solid tumors in the first phase of clinical trials and in the second phase of clinical trials in patients with nasopharyngeal tumors (Yeo et al. 2009). Clinical trials with CDK inhibitors partially confirmed the anticancer activity of this class of compounds and roscovitine (Cicenas et al. 2015); for example, clinical trial with roscovitine indicated a partial response in

PHYSIOLOGICAL RESEARCH • ISSN 1802-9973 (online) 
a patient with hepatocellular carcinoma and a sustained tumour stabilisation. Effective plasma levels of CDK inhibitors are in the micromolar range (Cicenas et al. 2015, van der Biessen et al. 2014).

Further optimization of roscovitine led to development of significantly more potent CDK inhibitors BA-12 and BP-14 (Zatloukal et al. 2013, Gucký et al. 2013). Both these compounds have shown anti-tumor activity in hepatocellular carcinoma (Haider et al. 2013). Interestingly, parallel modification of inhibitor BP-14, in which the 6-benzylaminopurine core was replaced with a 6-anilinopurine, led to compound BPA-302 with significantly different kinase selectivity and anticancer activity. BPA-302 displays nanomolar potency on the oncogenic receptor tyrosine kinase FLT3-ITD and selective cytotoxic activity in acute myeloid leukemia cell lines expressing FLT3-ITD (Gucký et al. 2018). There is hope that novel variants of CDK inhibitors will be even more successful. Results (Wang et al. 2020) are very promising, however, clinical trials will bring hopefully more significant outcomes (e.g. with novel CDK inhibitors). Details of in vitro studies as well as clinical trials are presented in (Cicenas et al. 2015). These findings stimulated our interest in further characterization of these compounds as drug candidates in terms of metabolic stability, drug interactions and pharmacokinetics.

CYPs are the most important enzymes of the first steps of drug metabolism (Anzenbacher and Anzenbacherová 2001, Anzenbacher and Zanger 2012, Ortiz de Montellano 2005, Zanger and Schwab 2013). These hemoproteins are localized in many tissues of the human organism (e.g. liver, lungs, brain, heart, kidney, and intestines). Subcellular localization of CYP enzymes is typically membrane of endoplasmatic reticulum and mitochondria (Šrejber et al. 2018). The main function of CYPs is formation of more polar metabolites of drugs either by inserting of polar group into parent molecule (e.g. hydroxylation) or by liberation of a present functional group (e.g. demethylation of a methoxy group). Fifty-seven human CYP forms are known; in pharmacology, focus is given to CYPs present in human liver, important in biotransformation of drugs (Anzenbacher and Anzenbacherová 2001, Anzenbacher and Zanger 2012, Guengerich 2003). Monitoring of drugdrug interactions is very important in the case of new potential drugs (Špičáková et al. 2016, Špičáková et al. 2019, Tománková et al. 2016).

We investigated the interactions between liver microsomal cytochromes P450 (CYP), which are the main enzymes of the first phase of metabolism of xenobiotics, and three kinase inhibitors: BP-21, BP-117 (both CDK inhibitors) and BPA-302 (FLT3-ITD inhibitor). Studies of interactions of these three potential drugs with CYPs and detection of possible metabolites formed by CYP enzymes are important for evaluation of drug-drug interactions, which may cause serious adverse effects (Anzenbacher and Anzenbacherová 2001). Molecular docking of BPA-302 was then performed to find how it interacts not with most sensitive CYPs.

For molecular docking, compound BPA-302 has been chosen as the most perspective kinase inhibitor among the three CDK inhibitors studied here. This compound (according to the results obtained) also interacts not only with the CYP2C19 form (a representative of structurally related CYP2C forms), but also with the CYP2D6 - known to metabolize about $20 \%$ of clinically used drugs metabolized by CYPs (Zanger and Schwab 2013).

\section{Methods}

\section{Chemicals and reagents}

BPA-302 ( $N^{2}$-(4-amino-cyclohexyl)-9cyclopentyl- $N^{6}$-(4-morpholin-4-ylmethyl-phenyl)- $9 H$ -

purine-2,6-diamine), BP-21 (4-\{9-cyclopentyl-6-((6furan-2-yl-pyridin-3-ylmethyl)-amino)-9H-purine-2ylamino $\}$-cyclohexanol) and BP-117 (1-\{9-cyclopentyl6-((6-furan-2-yl-pyridin-3-ylmethyl)-amino)- $9 H$-purine-

2-ylamino -2-methyl-propan-2-ol) were synthesized and characterized according to described procedures (Gucký et al. 2013, Gucký et al. 2018). Structures of tested compounds are shown in Fig. 1.

7-Ethoxyresorufin and ethoxy-4-(trifluoromethyl)coumarin were supplied by Fluka (Buchs, Switzerland). All other chemicals were purchased from Sigma Aldrich CZ (Prague, Czech Republic). All other common laboratory chemicals with the HPLC or analytical grade were obtained from the same company. Pooled human liver microsomes (HLM) were obtained from Biopredic (Rennes, France). Microsomes were obtained in accordance with ethical regulations of the country of origin (France). They were from seventeen donors (ten males and seven females) with a protein content of $25 \mathrm{mg} / \mathrm{ml}$ and total CYP content of $14.55 \mu \mathrm{mol} \cdot \mathrm{l}^{-1}$; CYP1A2, CYP2A6, CYP2B6, CYP2C8, CYP2C9, CYP2C19, CYP2D6, CYP2E1 and CYP3A4/5 enzyme activities were verified before the experiment with minimal consumption of the sample. 


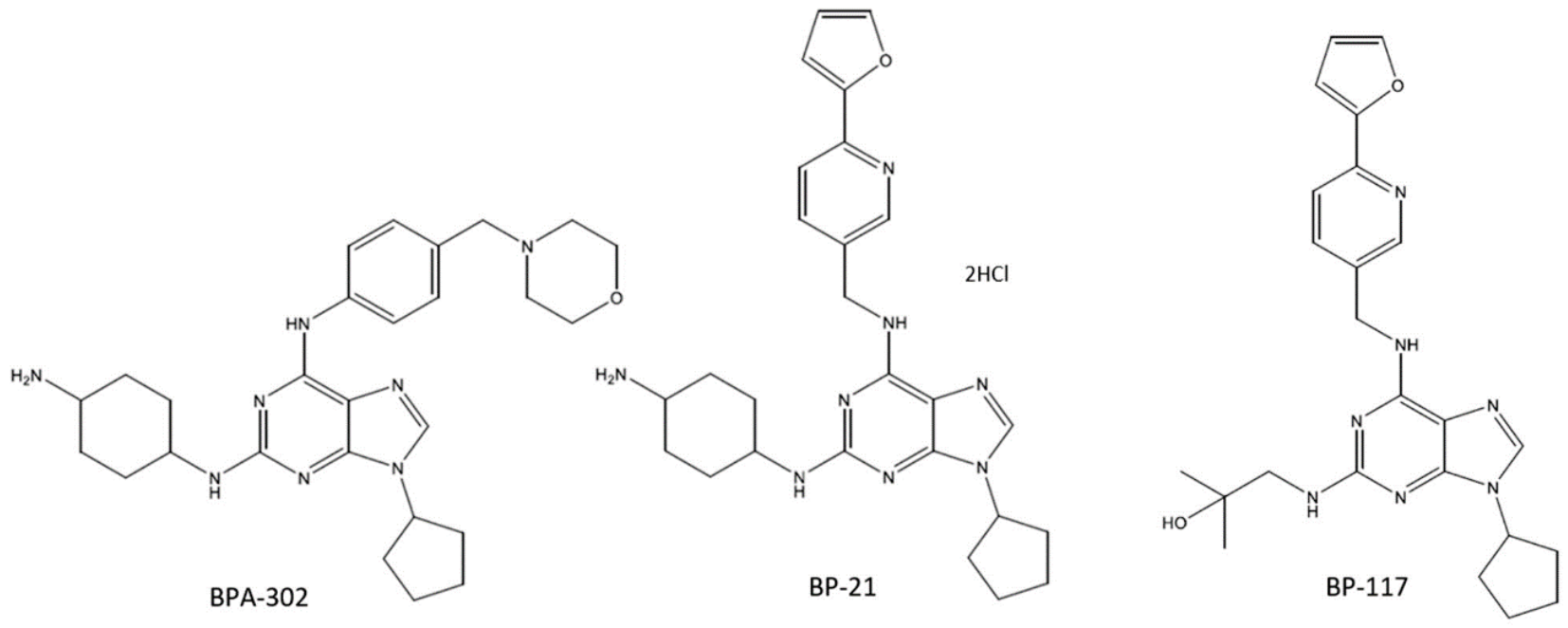

Fig. 1. Structures of tested compounds: BPA-302, BP-21 and BP-117.

Table 1. Incubation conditions for individual CYP assays used in the inhibition study.

\begin{tabular}{|c|c|c|c|c|c|c|c|}
\hline CYP & $\begin{array}{c}\text { Substrate } \\
\text { concentration } \\
\left(\mu \mathrm{mol} \cdot \mathrm{l}^{-1}\right)\end{array}$ & Substrate & $\begin{array}{l}\text { Reaction } \\
\text { catalyzed } \\
\text { by CYP }\end{array}$ & $\begin{array}{l}\text { Content } \\
\text { CYP } \\
\text { (nmol) }\end{array}$ & $\begin{array}{l}\text { Reaction } \\
\text { volume } \\
(\mu \mathrm{l})\end{array}$ & $\begin{array}{l}\text { Quench } \\
\text { reagent }\end{array}$ & $\begin{array}{c}\text { Method } \\
\text { of detection }\end{array}$ \\
\hline $1 A 2$ & 5.2 & 7-ethoxyresorufin & $O$-deethylation & 35 & 100 & $200 \mu \mathrm{l}$ methanol & $\begin{array}{l}\text { fluorescence } \\
\text { ex. } 535 \mathrm{~nm} \text {; } \\
\text { em. } 585 \mathrm{~nm}\end{array}$ \\
\hline $2 A 6$ & 15 & coumarin & 7-hydroxylation & 35 & 100 & $200 \mu$ l methanol & $\begin{array}{l}\text { fluorescence } \\
\text { ex. } 325 \mathrm{~nm} \text {; } \\
\text { em. } 450 \mathrm{~nm}\end{array}$ \\
\hline $2 B 6$ & 15 & $\mathrm{EFC}$ & $O$-deethylation & 35 & 100 & $200 \mu$ methanol & $\begin{array}{l}\text { fluorescence } \\
\text { ex.410 nm; } \\
\text { em. } 510 \mathrm{~nm}\end{array}$ \\
\hline $2 C 8$ & 150 & luciferin-ME & demethylation & 1000 & 50 & $\begin{array}{l}\text { luciferin detection } \\
\text { reagent }\end{array}$ & luminescence \\
\hline $2 C 9$ & 20 & diclofenac & 4'-hydroxylation & 35 & 200 & $\begin{array}{c}50 \mu \mathrm{l} \mathrm{ACN} / \mathrm{CH}_{3} \mathrm{COOH} \\
\text { luciferin detection }\end{array}$ & $\mathrm{UV}, 280 \mathrm{~nm}$ \\
\hline $2 C 19$ & 10 & luciferin-H EGE & 6'-hydroxylation & 250 & 50 & reagent & luminescence \\
\hline $2 D 6$ & 14.3 & bufuralol & 1 '-hydroxylation & 67 & 200 & $20 \mu \mathrm{l} 70 \% \mathrm{HClO}_{4}$ & $\begin{array}{l}\text { fluorescence } \\
\text { ex. } 252 \mathrm{~nm} \text {; } \\
\text { em. } 302 \mathrm{~nm}\end{array}$ \\
\hline $2 E 1$ & 26 & chlorzoxazon & $6 \beta$-hydroxylation & 160 & 1000 & $50 \mu \mathrm{l} 42.5 \% \mathrm{H}_{3} \mathrm{PO}_{4}$ & $\mathrm{UV}, 287 \mathrm{~nm}$ \\
\hline $3 A 4$ & 100 & testosterone & $6 \beta$-hydroxylation & 100 & 500 & $1001 \mathrm{Na}_{2} \mathrm{CO}_{3} / \mathrm{NaCl}$ & $\mathrm{UV}, 245 \mathrm{~nm}$ \\
\hline
\end{tabular}

Enzyme assays

All microsomal CYP activities were assayed according to well established protocols.

Following enzyme assays were performed to determine activities of specific CYP enzymes: CYP1A2, 7-ethoxyresorufin $O$-deethylation (Chang and Waxman
1998); CYP2A6, coumarin 7-hydroxylation (Soucek 1999); CYP2B6, 7-ethoxy-4-(trifluoromethyl) coumarin (EFC) O-deethylation (Donato et al. 2004); CYP2C8 luciferin-6'methyl ether (luciferin-ME) demethylation; CYP2C19, deoxyluciferin ethylene glycol ester (luciferin-H EGE) 6'-hydroxylation (Promega Technical 
Bulletin No.325, http://www.promega.com); CYP2C9, diclofenac 4'-hydroxylation (Crespi et al. 1998a); CYP2D6, bufuralol 1'-hydroxylation (Crespi et al. 1998b); CYP2E1, chlorzoxazone 6 $\beta$-hydroxylation (Lucas et al. 1996); CYP3A4/5, testosterone 6ß-hydroxylation (Guengerich et al. 1986).

Incubation mixtures contained $100 \mathrm{mmol} \cdot \mathrm{l}^{-1}$ potassium phosphate buffer ( $\mathrm{pH} 7.4)$, NADPH-generating system $\left(0.8 \mathrm{mmol} \cdot l^{-1} \mathrm{NADP}^{+}, 5.8 \mathrm{mmol} \cdot \mathrm{l}^{-1}\right.$ isocitrate, $0.3 \mathrm{unit} / \mathrm{ml}$ of isocitrate dehydrogenase and $8 \mathrm{mmol} \cdot \mathrm{l}^{-1}$ $\mathrm{MgCl}_{2}$ ), HLM and individual probe substrate. Assay conditions are listed in Table 1.

For determination of metabolites formed from specific substrates, Prominence LC-20A HPLC system (Shimadzu, Kyoto, Japan) with UV (6ß-hydroxychlorzoxazone, 4'-hydroxydiclofenac, 6 $\beta$-hydroxytestosterone) or with fluorescence detection (resorufin, 7-hydroxycoumarin, 7-hydroxy-4-(trifluoro-methyl)coumarin, 1'-hydroxybufuralol) was used. A TECAN Infinite M200 absorbance/fluorescence/ luminescence reader (Tecan, Vienna, Austria) was used for the detection of luciferin luminescence.

\section{Enzyme inhibition studies}

$\mathrm{K}_{\mathrm{M}}$ and $\mathrm{V}_{\max }$ values were determined for each enzyme assay to find the optimal concentration of the specific substrates for the inhibition experiments. Substrate concentration was chosen close to $\mathrm{K}_{\mathrm{M}}$. Data were analyzed using Sigma Plot v. 12.0 graphing software (Jandel Scientific, Chicago, IL, USA). Inhibition experiments were performed as three duplicate experiments at $0,3.9,7.8,15.63,31.25,62.5,125$, and $250 \mu \mathrm{mol} \cdot \mathrm{l}^{-1}$ concentration of each compound; individual values differed less than $10 \%$. Experimental conditions with tested compounds were the same as for determination of individual CYP activities (Table 1). Reaction mixtures were preincubated with potential inhibitors (BPA-302, BP-21 and BP-117) at $37{ }^{\circ} \mathrm{C}$ for $30 \mathrm{~min}$. Inhibition of individual CYP activities was in all cases evaluated by plotting respective remaining activity versus the inhibitor concentration.

\section{Statistical analysis}

Microsomal CYP activities obtained from enzyme inhibition studies were evaluated using Microsoft Excel 2016 (Microsoft Corporation, Redmond, WA, USA). All experimental data obtained from these studies were compared with data of controls (without the presence of tested inhibitor) using one-way ANOVA combined with Duncan multiple range test on the significance level of 0.01. Statistical analyses were performed with the Statistica software package (ver. 12; TIBCO Software, Inc., Palo Alto, CA, USA).

\section{Molecular docking}

The compound BPA-302 was prepared using MarvinSketch 15.1.5.0 software package (http://www.chemaxon.com) for molecular docking. Polar hydrogens were explicitly considered and Kollman charges assigned using AutoDock Tools program suite (Morris et al. 2009). Autodock Vina program (Trott et al. 2010) was used for docking of BPA-302 on a grid box containing the complete cytochrome P450 enzyme structure, which was centered close to the heme cofactor. The crystal structures of CYP2C19 (i.e., CYP2C19 with bound 4-hydroxy-3,5-dimethylphenyl)(2-methyl-1benzofuran-3-yl)methanone henceforth $0 \mathrm{XV}$, Protein Data Bank (PDB)ID: 4GQS (Reynald et al., 2012)) and CYP2D6 (with bound (4aR,6R,8aS)-8a-(2,4difluorophenyl)-6-(1H-pyrazol-4-yl)-4,4a,5,6,8,8a-hexahydropyrano(3,4-d)(1,3)thiazin-2-amine henceforth SI6, PDBID: 4XRZ (Brodney et al. 2015)) were used to construct the enzyme docking templates after removal of the bound ligand (0XV or SI6).

\section{Results}

\section{Inhibition of specific CYP activities in HLM}

In the present study, the potential inhibition of nine microsomal CYPs by kinase inhibitors BPA-302, BP-21 and BP-117 was studied. At first, enzyme kinetics of individual CYP forms was determined using standard substrates. Experiments assessing the inhibition of enzyme activities of nine CYP forms by BPA-302, BP-21 or BP-117 were then performed. Fig. 2 shows summarized results of the inhibition experiments (Fig. 2A, for BPA-302; Fig. 2B, for BP-21; Fig. 2C for BP-117). Compound BPA-302 inhibits significantly the CYP2C19 activity to $22 \%$ of the corresponding control; this is however apparent only at higher concentrations $\left(62.5-250 \mu \mathrm{mol} \cdot \mathrm{l}^{-1}\right.$, Fig. 2A). It also inhibits the CYP2D6 activity in a concentrationdependent manner; however, the extent of inhibition is relatively small (decrease of activity to $50-35 \%$ at two highest levels of the inhibitor). Both the BP-21 and BP-117, are able to inhibit the CYP2C9 (to $19 \%$ of corresponding control, and to $17 \%$ of corresponding control, respectively), and CYP2C19 (to $13 \%$ 
of corresponding control, and to $6 \%$, respectively) activities at the highest concentration of inhibitor (250 $\mu \mathrm{mol} \cdot \mathrm{l}^{-1}$, Fig. 2B, 2C). In all cases of tested compounds (BPA-302, BP-21 and BP-117) the CYP2C19 was the most affected and its $\mathrm{IC}_{50}$ value was determined as follows: $\quad \mathrm{IC}_{50}=28.86 \pm 12.69 \mu \mathrm{mol} \cdot 1^{-1}$; $34.07 \pm 4.91 \mu \mathrm{mol} \cdot 1^{-1} ; 23.88 \pm 9.02 \mu \mathrm{mol} \cdot 1^{-1}$, respectively.

\section{Molecular modelling}

The BPA-302 was docked into crystal structures of CYP2C19 and CYP2D6 in order to assess its binding to active sites of the respective enzymes. Both enzymes structures contained bound ligand (OXV see Methods), which was removed before the docking experiment. An applicability of the used docking method was evaluated by re-docking of the ligand, which was present in the used crystal structures. In both cases the docking identified the native ligand position as the most favorable (Figs. 3A and 3C).

2A

BPA-302

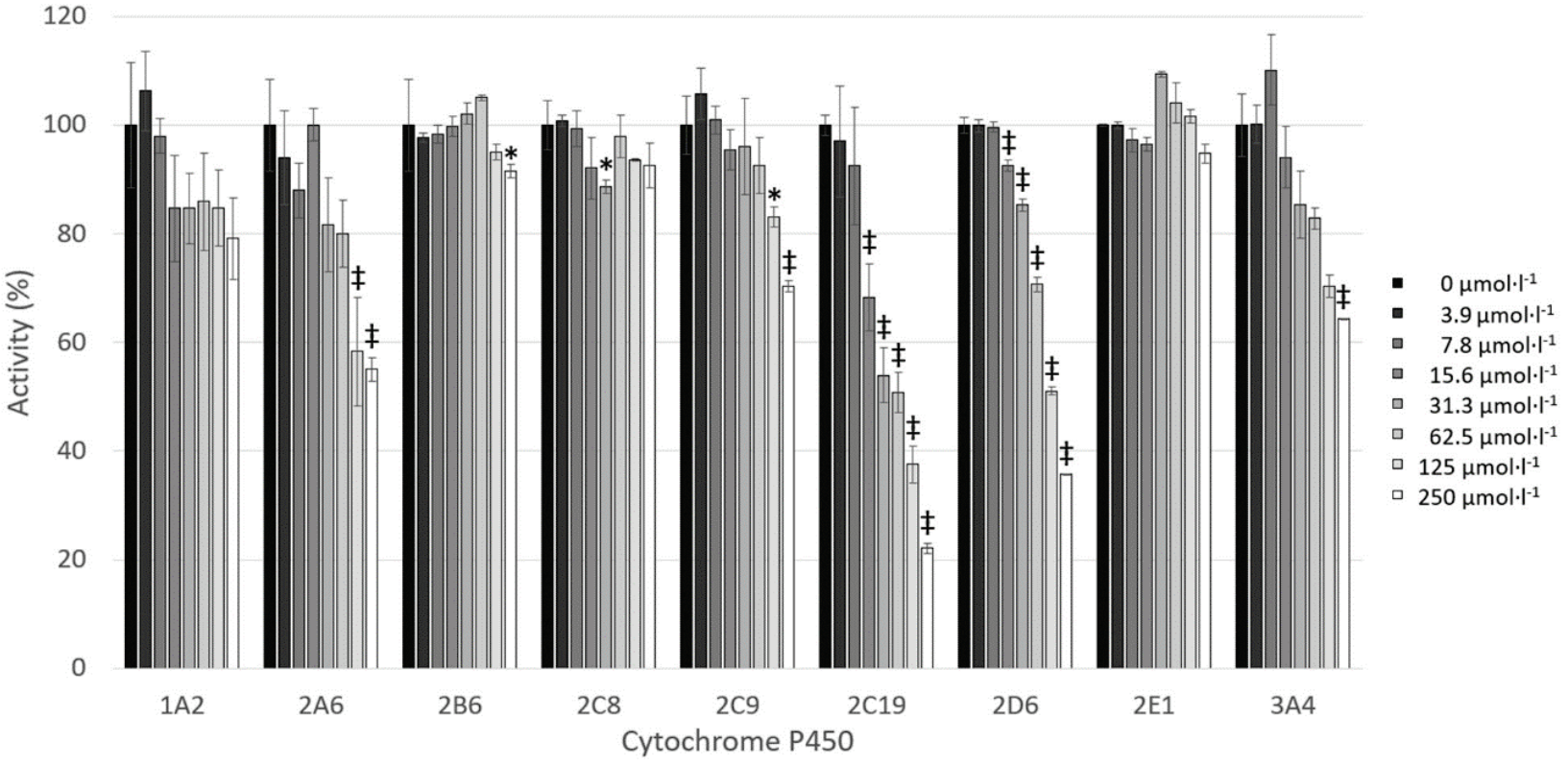

2B

120

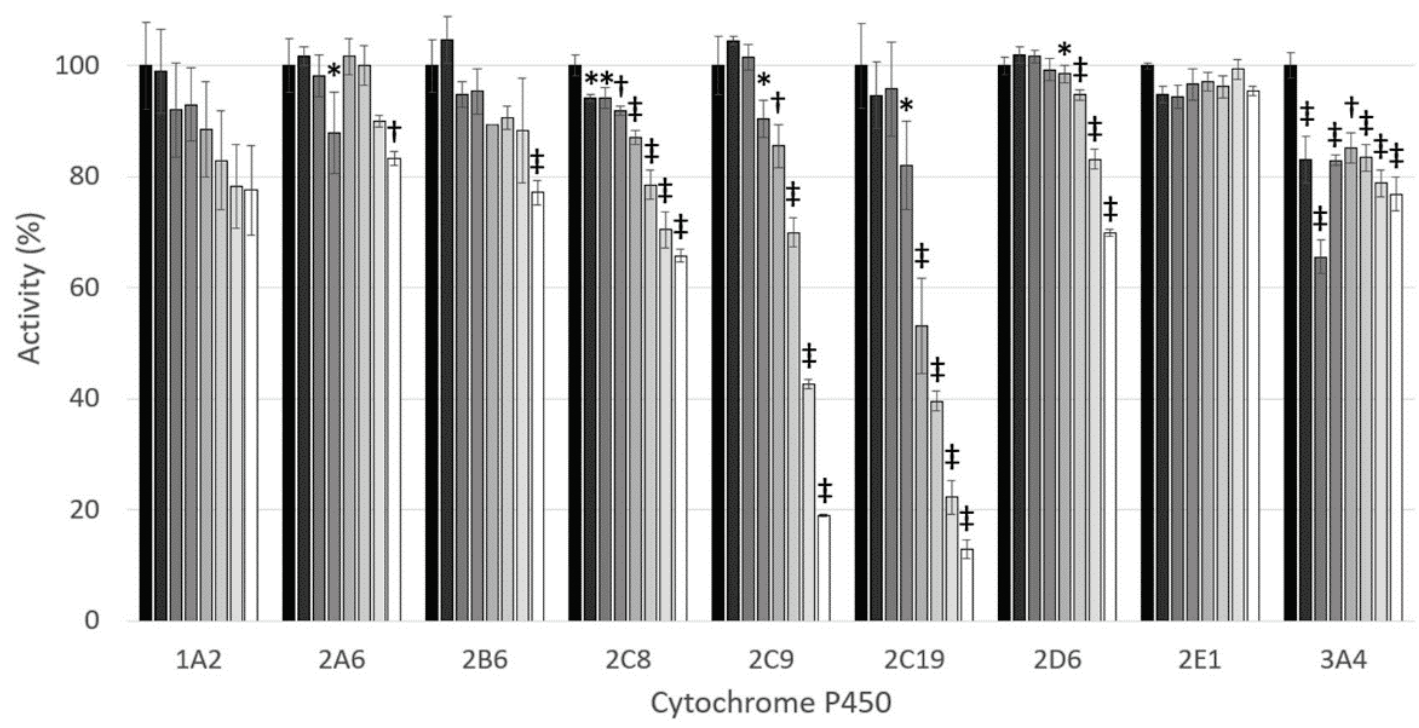

- $0 \mu \mathrm{mol} \cdot \mathrm{I}^{-1}$

- $\quad 3.9 \mu \mathrm{mol} \cdot \mathrm{I}^{-1}$

- $\quad 7.8 \mu \mathrm{mol}^{-1}$

- $\quad 15.6 \mu \mathrm{mol} \cdot \mathrm{I}^{-1}$

ㅁ $31.3 \mu \mathrm{mol} \cdot \mathrm{l}^{-1}$

- $62.5 \mu \mathrm{mol} \cdot \mathrm{l}^{-1}$

ㅁ $125 \mu \mathrm{mol} \cdot \mathrm{l}^{-1}$

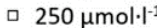


$2 \mathrm{C}$

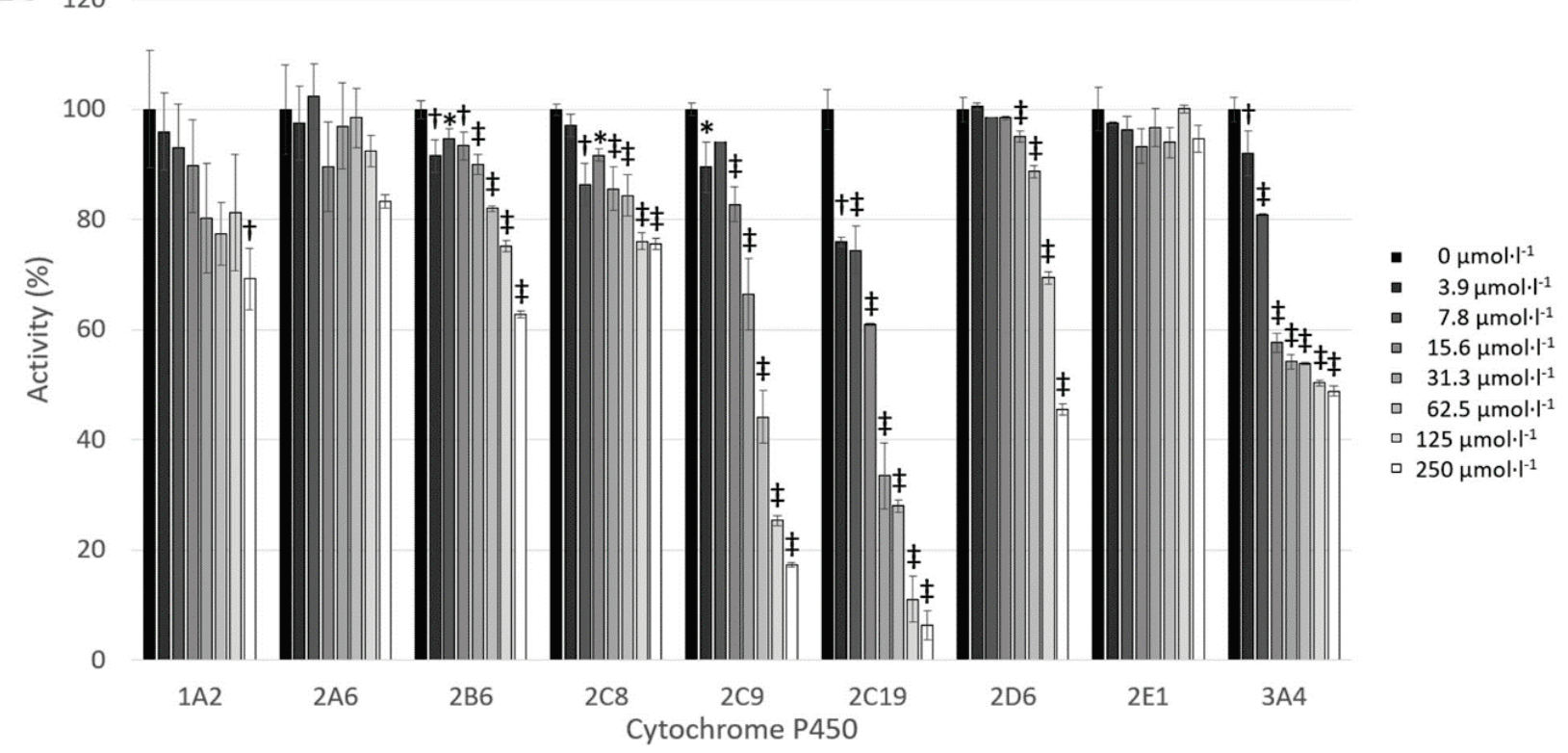

Fig. 2. Effects of studied kinase inhibitor (A) BPA-302, (B) BP-21 and (C) BP-117 on enzyme activities of CYP1A2, CYP2A6, CYP2B6, CYP2C8, CYP2C9, CYP2C19, CYP2D6, CYP2E1 and CYP3A4 in HLM. Inhibition of enzyme activity is expressed as the activity remaining relative to control (100\%, without kinase inhibitor) in percent. Concentration of an individual kinase inhibitor in the reaction mixture was $0,3.9,7.8,15.6,31.3 ., 62.5,125$ and $250 \mu \mathrm{mol} \cdot \mathrm{l}^{-1}$. Activities represent the mean \pm standard deviation; $\mathrm{N}=3$. A significant decrease of metabolite concentration measured in experimental sample vs. control (sample with $0 \mu \mathrm{mol} \cdot \mathrm{l}^{-1}$ of kinase inhibitor) is labeled $(* p<0.01,+p<0.001, \neq p<0.0001)$.

\section{CYP2C19}

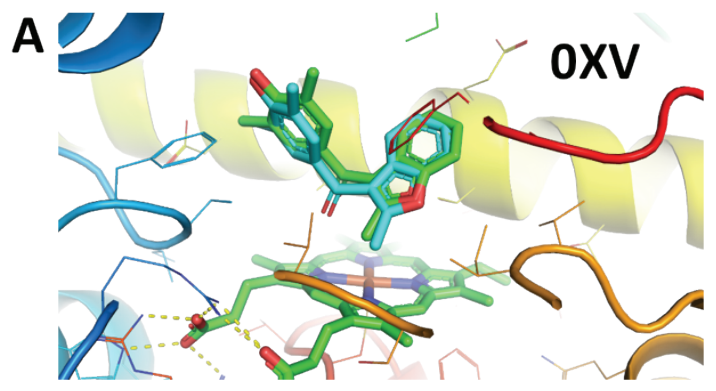

$-9.9 \mathrm{kcal} / \mathrm{mol}$

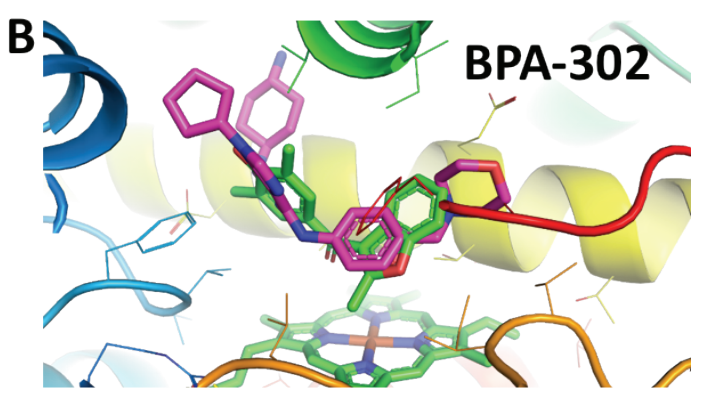

$-9.0 \mathrm{kcal} / \mathrm{mol}$

CYP2D6
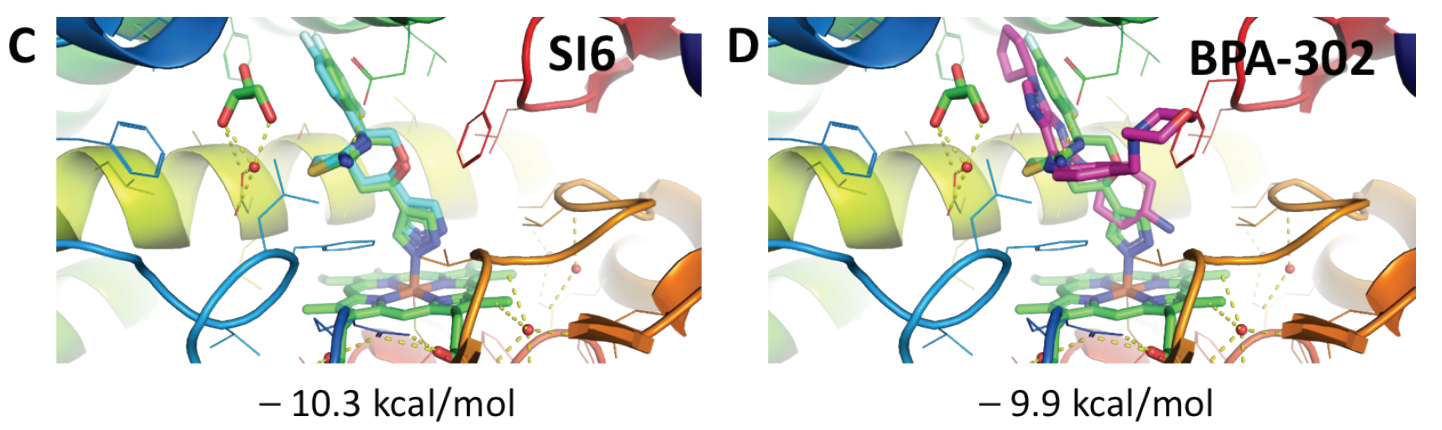

Fig. 3. Structures of CYP2C19 (panels A and B) and CYP2D6 (C and D) active sites with heme cofactor and ligands shown in stick models. Carbon atoms of crystal structures-of hemes and docked structures 0XV (CYP2C19, Figs. A and B) and SI6 (CYP2D6, Figs. C and D) are shown in green, oxygen atoms in red. The CYP I-helix, a typical structural motif of both CYPs, is shown by yellow curl. Reliability of docking procedure used documented by a re-docking of OXV and SI6 (in panels A and C in turquoise) close to the original positions of OXV and SI6 observed in (in panels A and C in green). BPA-302 docked to CYP2C19 and CYP2D6, in panels B and D, in magenta (crystal positions of PDB ligands OXV and SI6 in both cases again in green for comparison). The energies in $\mathrm{kcal} / \mathrm{mol}$ are estimated binding affinities by Autodock Vina. Hydrogens are not shown for clarity. 
The docking experiment of BPA-302 into CYP2C19 active site (Fig. 3B) showed that BPA-302 binds into the CYP active site with a phenyl ring positioned above the heme cofactor. The bonding afinity $9.0 \mathrm{kcal} / \mathrm{mol}$ was only slightly weaker than the binding activity of $0 \mathrm{XV}-9.9 \mathrm{kcal} / \mathrm{mol}$, which may indicate rather comparative binding affinities of both ligands to CYP2C19 active site. In the case of CYP2D6 docking experiment, BPA-302 bounded to the active site with affinity of $-9.9 \mathrm{kcal} / \mathrm{mol}$, which was only slightly weaker that the predicted affinity of SI6 $(-10.3 \mathrm{kcal} / \mathrm{mol})$. These results clearly indicate that BPA-302 can bind to active sites of both CYP2C19 and CYP2D6 enzymes above the heme cofactor corroborating the experimental data.

\section{Discussion}

2,6,9-trisubstituted purines have been developed as CDK inhibitors and $(R)$-roscovitine entered clinical trials as candidate anticancer drug. Its pharmacokinetics and metabolism was already described (McClue and Stuart 2008, Nutley et al. 2005). Few its analogues were also studied in terms of metabolic stability and interactions with CYPs (Chmela et al. 2001, Rypka et al. 2002, Šiller et al. 2009).

Results of the in vitro experiments with related compounds show that neither of the three kinase inhibitors show reasonable inhibitory effect on enzyme activities of CYP1A2, 2A6, 2B6, 2C8, 2C9, 2D6, 2E1, and 3A4. In contrast, compound BPA-302 inhibits significantly the CYP2C19 activity to $22 \%$ of the corresponding control; this is however apparent only at the higher concentration (62.5 - $250 \mu \mathrm{mol} \cdot \mathrm{l}^{-1}$, Fig. 2A). This compound is also able to inhibit also the CYP2D6 activity in a concentration-dependent manner. Given the fact that BPA-302 is acting at low nanomolar concentrations specifically in acute myeloid leukemia models (Gucky et al. 2018), inhibition of these two CYPs seems not to be clinically relevant issue. The docking experiment showed that BPA-302 can bind into active site of both CYP2C19 and CYP2D6 with estimated binding affinity of -9.0 and $-9.9 \mathrm{kcal} / \mathrm{mol}$, respectively, close to the values obtained with bioactive ligands $0 \mathrm{XV}$ and SI6 known to strongly bind to these two CYP proteins (Reynald et al. 2012, Brodney et al. 2015). Both BP-21 and BP-117 are able to inhibit the CYP2C9 (to $19 \%$ of corresponding control, and to $17 \%$ of corresponding control, respectively) and CYP2C19 (to $13 \%$ of corresponding control, and to $6 \%$, respectively) activities at the highest concentration of inhibitor $\left(250 \mu \mathrm{mol} \cdot \mathrm{l}^{-1}\right.$, Fig. 2B, 2C). Hence, the docking experiment confirmed the possibility of a relatively strong interaction of the kinase inhibitor BPA-302 with these two CYP enzymes.

The determined $\mathrm{IC}_{50}$ values of BPA-302, BP-21 and $\mathrm{BP}-117 \quad\left(\mathrm{IC}_{50}=28.86 \pm 12.69 \mu \mathrm{mol} \cdot \mathrm{l}^{-1} ; \quad 34.07 \pm\right.$ $4.91 \mu \mathrm{mol} \cdot \mathrm{l}^{-1} ; \quad 23.88 \pm 9.02 \mu \mathrm{mol} \cdot \mathrm{l}^{-1}, \quad$ respectively) indicate a strong interaction of tested compounds with CYP2C19. Drugs metabolized by this enzyme are often proton pump inhibitors (PPIs), such as omeprazole and pantoprazole, as well as the prodrug clopidogrel, which is activated to effective anticoagulant (McTavish et al. 1991). Co-administration of BP-117 with drugs metabolised by CYP2C19 could lead (because of its interaction with PPI) to increased gastric acid production, gastric ulcers, duodenal ulcers, etc.; in the case of clopidogrel it could lead to bleeding (McTavish et al. 1991, Zanger and Schwab 2013). In other words, a possibility of this effect should be considered when higher doses and concentrations are used and clinical investigation of this interaction should be considered and further examined. On the other hand, the real possibility of drug interaction in clinical praxis is less probable as the plasma levels of CDK inhibitors (as reported from clinical data) are in the micromolar range (Cicenas et al. 2015, van der Biessen et al. 2014).

Taken together, the results obtained show that the kinase inhibitors studied are promising drug candidates, at least because of their relatively low potential to inhibit the liver CYP enzymes. However, the possibility of this interaction should be considered, namely, because of known inter-individual variations in drug metabolism (Anzenbacher and Zanger 2012, Zanger and Schwab 2013). Apparently, the studies of this kind deserve a continuation aimed e.g. at CYP3A4 and other CYP enzymes. Possibly, studies on the interaction with CYP enzymes should be oriented not only to these involved in drug metabolism, but also with other CYP forms, activity of which may be influenced by interaction with biologically active substances and xenobiotics (as e.g. CYPs involved in steroidogenesis).

\section{Conflict of Interest}

There is no conflict of interest.

\section{Acknowledgements}

This work was supported by internal student grant of UPOL (IGA_LF_2019_011, IGA_LF_2020_009), by 
Czech Ministry of Health of the Czech Republic grant nr.17-28231A and by the Ministry of Education, Youth and Sports project Toxicology

CZ.02.2.69/

\section{References}

ANZENBACHER P, ANZENBACHEROVÁ E: Cytochromes P450 and metabolism of xenobiotics. Cell Mol Life Sci 58: 737-747, 2001. https://doi.org/10.1007/PL00000897

ANZENBACHER P, ZANGER UM: Metabolism of Drugs and Other Xenobiotics. Wiley-VCH Verlag \& Co KGaA, Germany, 2012. https://doi.org/10.1002/9783527630905

BRODNEY MA, BECK EM, BUTLER CR, BARREIRO G, JOHNSON EF, RIDDELL D, PARRIS K, NOLAN CE, FAN Y, ATCHISON K, GONZALES C, ROBSHAW AE, DORAN SD, BUNDESMANN MW, BUZON L, DUTRA J, HENEGAR K, LACHAPELLE E, HOU X, ROGERS BN, PANDIT J, LIRA R, MARTINEZALSINA L, MIKOCHIK P, MURRAY JC, OGILVIE K, PRICE L, SAKYA SM, YU A, ZHANG Y, O'NEILL BT: Utilizing structures of CYP2D6 and BACE1 complexes to reduce risk of drug-drug interactions with a novel series of centrally efficacious BACE1 inhibitors. J Med Chem 58: 3223-3252, 2015. https://doi.org/10.1021/acs.jmedchem.5b00191

CICENAS J, KALYAN K, SOROKINAS A, STANKUNAS E, LEVY J, MESKINYTE I, STANKEVICIUS V, KAUPINIS A, VALIUS M: Roscovitine in cancer and other diseases. Ann Transl Med 3: 135, 2015.

CRESPI CL, CHANG TKH, WAXMAN DJ: Determination of CYP2C9-catalyzed diclofenac 4' hydroxylation by highperformance liquid chromatography. In: Cytochrome P450 Protocols. IR PHILLIPS, EA SHEPHARD (eds), Humana, Totowa, USA, 1998a, pp 109-113. https://doi.org/10.1385/1-59259-998-2:109

CRESPI CL, CHANG TKH, WAXMAN DJ: CYP 2D6-dependent bufuralol 1' hydroxylation assayed by reversedphase ion-pair high-performance liquid chromatography with fluorescence detection. In: Cytochrome P450 Protocols. IR PHILLIPS, EA SHEPHARD (eds), Humana, Totowa, USA, 1998b, pp 141-146. https://doi.org/10.1385/0-89603-519-0:141

DONATO MT, JIMENEZ N, CASTELL JV, GOMEZ-LECHON MJ: Fluorescencebased assays for screening nine cytochrome P450 (P450) activities in intact cells expressing individual human P450 enzymes. Drug Metab Dispos 32: 699-706, 2004. https://doi.org/10.1124/dmd.32.7.699

GUCKÝ T, JORDA R, ZATLOUKAL M, BAZGIER V, BERKA K, ŘEZNÍČKOVÁ E, BÉRES T, STRNAD M, KRYŠTOF V: A novel series of highly potent 2,6,9-trisubstituted purine cyclin-dependent kinase inhibitors. J Med Chem 56: 6234-6247, 2013. https://doi.org/10.1021/jm4006884

GUCKÝ T, ŘEZNÍČKOVÁ E, RADOŠOVÁ MUCHOVÁ T, JORDA R, KLEJOVÁ Z, MALÍNKOVÁ V, BERKA K, BAZGIER V, AJANI H, LEPŠÍK M, DIVOKÝ V, KRYŠTOF V: Discovery of N2-(4-amino-cyclohexyl)-9cyclopentyl-N6-(4-morpholin-4-ylmethyl-phenyl)-9H-purine-2,6-diamine as a potent FLT3 kinase inhibitor for acute myeloid leukemia with FLT3 mutations. J Med Chem 61: 3855-3869, 2018. https://doi.org/10.1021/acs.jmedchem.7b01529

GUENGERICH FP. Cytochromes P450, drugs, and diseases. Mol Interv 3: 194-204, 2003. https://doi.org/10.1124/mi.3.4.194

GUENGERICH FP, MARTIN MV, BEAUNNE PH, KTEMERS P, WOLFF T, WAXMAN DJ: Characterization of Rat and human-liver microsomal cytochrome-P-450 forms involved in nifedipine oxidation, a prototype for genetic-polymorphism in oxidative drug-metabolism. J Biol Chem 261: 5051-5060, 1986.

HAIDER C, GRUBINGER M, ŘEZNÍČKOVÁ E, WEISS TS, ROTHENEDER H, MIKLOS W, BERGER W, JORDA R, ZATLOUKAL M, GUCKÝ T, STRNAD M, KRYŠTOF V, MIKULITS W: Novel inhibitors of cyclindependent kinases combat hepatocellular carcinoma without inducing chemoresistance. Mol Cancer Ther 12: 1947-1957, 2013. https://doi.org/10.1158/1535-7163.MCT-13-0263

HANAHAN D, WEINBERG RA: Hallmarks of cancer: the next generation. Cell 144, 646 674, 2011. https://doi.org/10.1016/j.cell.2011.02.013

CHANG TKH, WAXMAN DJ: Enzymatic analysis of cDNA-expressed human CYP1A1, CYP1A2 and CYP1B1 with ethoxyresorufin as a substrate. In: Cytochrome P450 Protocols. IR PHILLIPS, EA SHEPHARD (eds), Humana, Totowa, USA, 1998, pp 103-122. https://doi.org/10.1385/0-89603-519-0:103 
LUCAS D, MENEZ JF, BERTHOU F: Chlorzoxazone: an in vitro and in vivo substrate probe for liver CYP2E1. Methods Enzymol 272: 115-123, 1996. https://doi.org/10.1016/S0076-6879(96)72014-1

MCCLUE SJ, STUART I: Metabolism of the trisubstituted purine cyclin-dependent kinase inhibitor seliciclib (r-roscovitine) in vitro and in vivo. Drug Metab Dispos 36: 561-570, 2008. https://doi.org/10.1124/dmd.107.019232

MCTAVISH D, BUCKLEY MMT, HEEL RC: Omeprazole. An updated review of its pharmacology and therapeutic use in acid-related disorders. Drugs 42: 138-170, 1991. https://doi.org/10.2165/00003495-199142010-00008

MORRIS GM, HUEY R, LINDSTROM W, SANNER MF, BELEW RK, GOODSELL DS, OLSON AJ: Autodock4 and AutoDockTools4: automated docking with selective receptor flexibility. J Comp Chem 16: 2785-2791, 2009. https://doi.org/10.1002/jcc.21256

NUTLEY BP, RAYNAUD FI, WILSON SC, FISCHER PM, HAYES A, GODDARD PM, MCCLUE SJ, JARMAN M, LANE DP, WORKMAN P: Metabolism and pharmacokinetics of the cyclin-dependent kinase inhibitor R-roscovitine in the mouse. Mol Cancer Ther 4: 125 139, 2005.

OTTO T, SICINSKI P: Cell cycle proteins as promising targets in cancer therapy. Nat Rev Cancer 17: 93-115, 2017. https://doi.org/10.1038/nrc.2016.138

ORTIZ DE MONTELLANO PR (ed): Cytochrome P450: Structure, Mechanism, and Biochemistry. 3rd edition. New York: Kluwer Academic/Plenum, 2005. https://doi.org/10.1007/b139087

REYNALD RL, SANSEN S, STOUT CD, JOHNSON EF: Structural characterization of human cytochrome P450 2C19: active site differences between P450s 2C8, 2C9, and 2C19. J Bio Chem 287: 44581-44591, 2012. https://doi.org/10.1074/jbc.M112.424895

SOUČEK P: Novel sensitive high-performance liquid chromatographic method for assay of coumarin 7-hydroxylation. J Chromatogr B 734: 23-29, 1999. https://doi.org/10.1016/S0378-4347(99)00325-4

ŠILLER M, ANZENBACHER P, ANZENBACHEROVÁ E, DOLEŽAL K, POPA I, STRNAD M: Interactions of olomoucine II with human liver microsomal cytochromes P450. Drug Metab Dispos 37: 1198-1202, 2009. https://doi.org/10.1124/dmd.108.025502

ŠPIČÁKOVÁ A, BAZGIER V, SKÁLOVÁ L, OTYEPKA M, ANZENBACHER P: $\beta$ caryophyllene oxide and transnerolidol affect enzyme activity of CYP3A4 - in vitro and in silico studies. Physiol Res 68 (Suppl 1): S51-S58, 2019. https://doi.org/10.33549/physiolres.934323

ŠPIČÁKOVÁ A, ANZENBACHER P, LIŠKOVÁ B, KUČA K, FUSEK J, ANZENBACHEROVÁ E: Evaluation of possible inhibition of human liver drug metabolizing cytochromes p450 by two new acetylcholinesterase oxime-type reactivators. Food Chem Toxicol 88:100-104, 2016. https://doi.org/10.1016/j.fct.2015.11.024

ŠREJBER M, NAVRÁTILOVÁ V, PALONCÝOVÁ M, BAZGIER V, BERKA K, ANZENBACHER P, OTYEPKA M: Membrane-attached mammalian cytochromes P450: An overview of the membrane's effects on structure, drug binding, and interactions with redox partners. J Inorg Biochem 183: 117-136, 2018. https://doi.org/10.1016/j.jinorgbio.2018.03.002

TOMÁNKOVÁ V, VLČKOVÁ A, ANZENBACHER P, BACHLEDA P, ANZENBACHEROVÁ E: The use of goldenrod general (Solidago virgaurea) preparations does not influence the metabolism of concomitantly administered drugs. Klin Farmakol Farm 30: 5-10, 2016. https://doi.org/10.36290/far.2016.002

TROTT O, OLSON AJ: Software news and update autodock vina: improving the speed and accuracy of docking with a new scoring function, efficient optimization, and multithreading. J Comput Chem 31: 455-461, 2010. https://doi.org/10.1002/jcc.21334

VAN DER BIESSEN DA, BURGER H, DE BRUIJN P, LAMERS CH, NAUS N, LOFERER H, WIEMER EA, MATHIJSSEN RH, DE JONGE MJ: Phase I study of RGB-286638, a novel, multitargeted cyclin-dependent kinase inhibitor in patients with solid tumors. Clin Cancer Res 20: 4776-83, 2014. https://doi.org/10.1158/1078-0432.CCR-14-0325

WANG X, DENG K, WANG C, LI Y, WANG T, HUANG Z, MA Y, SUN P, SHI Y, YANG S, FAN Y, XIANG R: Novel CDKs inhibitors for the treatment of solid tumour by simultaneously regulating the cell cycle and transcription control. J Enzyme Inhib Med Chem 35: 414-423, 2020. https://doi.org/10.1080/14756366.2019.1705290 
YEO W, GOH B, LE TOURNEAU C, GREEN SR, CHIAO JH, SIU LL: A phase II randomized study of oral seliciclib in patients with previously treated nasopharyngeal carcinoma. J Clin Oncol 27, 2009. https://doi.org/10.1200/jco.2009.27.15 suppl.6026

ZANGER UM, SCHWAB M: Cytochrome P450 enzymes in drug metabolism: regulation of gene expression, enzyme activities, and impact of genetic variation. Pharmacol Ther 138: 103 141, 2013. https://doi.org/10.1016/j.pharmthera.2012.12.007

ZATLOUKAL M, JORDA R, GUCKÝ T, REZNICKOVA E, VOLLER J, POSPISIL T, MALINKOVA V, ADAMCOVA H, KRYSTOF V, STRNAD M: Synthesis and in vitro biological evaluation of 2,6,9-trisubstituted purines targeting multiple cyclin-dependent kinases. Eur J Med Chem 61: 61-72, 2013. https://doi.org/10.1016/j.ejmech.2012.06.036 